\title{
THE IMAGE OF THE ROMANIAN WOMAN IN “NEVER MIND THE BALKANS, HERE'S ROMANIA” BY MIKE ORMSBY
}

\author{
Gabriela MIHĂILĂ-LICĂ \\ “Nicolae Bălcescu” Land Forces Academy, Sibiu, Romania \\ mihailag2001@yahoo.com
}

\begin{abstract}
The paper analyses the image of the contemporary Romanian woman as it appears in the book "Never Mind the Balkans, Here's Romania", written by Mike Ormsby and published in 2008. The book of the English writer is a collection of 57 stories that present various aspects of the Romanian life from the period between 1994-2008 when Ormsby visited Romania. Even though the gallery of characters he focuses on is created from people from all over Romania and from all the strata of the society, one can discover some common characteristics of the Romanian women. They have the most varied occupations (managers, veterinarians, opera singers, publishers, etc.) and display the most varied character traits, yet the careful reader is able to discern the vivid portrait of the "generic" Romanian woman.
\end{abstract}

KEYWORDS: image, social, classes, Romania, $19^{\text {th }}$ century

\section{Introduction}

In 'Never Mind the Balkans, Here's Romania", Mike Ormsby writes about a country that makes the transition from the Communist period to the status of member of the European Union. It is a period characterized by numerous changes that take place at a tremendous speed, in all fields of life and people try to adapt to these, sometimes by changing themselves, with various degrees of success. The women's personality and behavior appear to reflect to a higher extent than in the case of men the changes the transition period brings about. There is a clash between two mentalities as well as between the old conservative fearful behaving and the new aggressive manner of acting, very few succeeding in finding a balance.

\section{Girls}

One of the few portraits of girls that appear in the book is that of the brown-eyed, pig-tailed Catrinel, the sociable daughter of one of Michael Ormby's friends, a real artist with an eye for colour and composition. She speaks German and Romanian and is extremely clever, top of her class, yet her parents are worried she might not get at a good school near their home as there had been "lots of clever parents lying about their addresses". Catrinel's portrait is followed by that of another girl the author meets at a bar. The nine-year old participates in a children's party there. What strikes the onlookers about her is the fact that she has her hair dyed blond, "three or four different shades, like a model". She also wears make-up and high hills and orders coke from the bartender without saying please or thank you. One of the taxi drivers in Bucharest generalizes saying that what all the children want is computers, clothes and Coke and that they have no more respect for the older people. 


\section{Young Women}

The gallery of young women is richly populated and even though almost all the feminine characters in it have both qualities and defects, the reader can easily differentiate between the ones that meet with the approval of the writer versus the ones that do not.

The first encounter with a Romanian woman that the writer presents is that of the driver who gives him a ride through rural Romania, at tremendous speed and without total disregard for all the traffic rules. She and her husband are young people "with jobs and money, style and brains". Nevertheless, they believe that the Europeans who stick to the speed limit when there are no cops around are stupid. The husband mocks the foreigner's fear and even seems to enjoy it. He encourages her reckless driving until she almost gets them killed. The reader does not sense the women's need for the rush of adrenaline; it is more about trying to prove herself and to stay in the men's world.

Some of the women have resigned and are just trying to survive in this new harsh aggressive world where some are seen as decorative objects that can fulfill menial jobs, like the assistant of the dentist he goes to. She listens to the sexist jokes of the men around and keeps silent to her boss's comments.

The clerk at the post office has developed another coping mechanism: she gives absurd answers to the customers' questions, aware, but accustomed to the absurd bureaucratic system that she now helps to perpetuate.

Ruxi, the wife of his friend, Cata, is an example of trophy girlfriend: she has bright green eyes, blonde hair and an infectious giggle. She flaunts her slim body from the handle of the trolley, perches on high heels, pouts at the rag dolls as she and her friends pass the toy section. She goes to barbecues with Cata who gets drunk with the buddies and ignores her. In order to pass time, she talks on the phone with her mother who is writing her college essay. She is part of the same category of the glamorous girls who laugh and joke swigging Fanta at the shiny kiosks in the big railway station. At night, if they have money, they go to expensive clubs wearing elegant cloths with deep cleavages, get drunk and push aside those who get into their limelight, even though very few people dance. The younger poorer girls, who probably have not benefited from too much education, hang around with guys who "scowl and spit, laugh and joke, stub out cigarettes" and "listen to turbo-folk music at a volume likely to induce nosebleeds in small children and angina attacks in the elderly". The only place where the narrator can escape the "cigarette-puffing, shade wearing babes and spiky haired guys with steel studs in their eyeballs" is the opera. There is a sharp contrast between the artists who are supposed to make the world nicer and awaken cathartic feelings in the ones who come to admire them and the fierce competition that takes place on the stage in plain view of the audience. Some of the leading singers do not hesitate to humiliate a younger colleague and boycott her performance.

In opposition to these, he presents Adina, who is caring, intelligent and kind and who takes care of a dog she saves from the children who were torturing it.

Another woman from this category, whom the author befriends, is his neighbor, Lumi, who helps him "to navigate" through the administrative obstacles entailed by living in a Romanian block of flats.

This group also includes Laura, a "young and brainy, tall and skinny, beautiful and hip" young woman, "liable to explode at any time over nothing, who left Braila in order to get based in New York". She openly expresses her anger at the bribe she is asked to pay at the airport understanding that this disease needs to be eradicated for Romania to prosper. 
Ioana is also an immigrant, living in Switzerland, and she does not get the job she has dreamed of because of the lies of another Romanian woman. The author understands that this is an exemplification of the Capra Vecinului - the Neighbour's Goat saying.

The manager of the Costalot hotel, despite being an educated woman in her early thirties, creates an extremely bad impression when she does not observe the booking rules and condones bribery.

Youth is no guarantee for respect for one's health and for the health of others either. Thus, the wife of his dentist smokes like a steam train despite being six months pregnant.

One of the events that help the author get better acquainted with the young generation of Romanian women is his advertising for an office assistant. Those who apply are almost all female and the great majority of them want to get the job for the wrong reasons.

Nicole is the type of young woman who has had access to high quality education, but, unlike her sister, she has also learned how to trust her instinct. That is why, when she notices that her nephew is unwell, she calls for the pediatrician to check on him and thus manages to save him from starvation.

Some of the women show a generosity that touches the author, like the young female vet who promises to operate for free on the injured cat he takes to the hospital.

Another occasion that enables Ormsby to observe the Romanian women is the Women's Day when all the women look nice "walking around clutching flowers". Nevertheless, we are presented, shortly after this, a scene that takes place at a ballet show where a woman cries because she has been punched in the face by a man. It is a modality of reminding the readers that even though progresses have been made in this respect, women are still vulnerable. Being a Roma woman comes with additional difficulties due to ethnic prejudice. The author understands this reality after witnessing the attempts of a gypsy mother to get herself and her many children a cab. However, he also witnesses the robbing of some unsuspecting people by three Roma girls who stalk their prey like lionesses on Animal Planet. Poverty and the lack of education could be some of the reasons for this behavior.

Ormsby dedicates several of his stories to the women who have jobs, jobs that used to be considered a male preserve for a long period of time. He demonstrates that the contemporary Romanian women can be both beautiful and smart, the physical beauty often being a reflection of the moral one.

The author is not amazed by the great number of guys who come at the library when he notices the librarian who is "quite a picture".

Adela, an ex-student of the writer, invites him to visit her and her family and she also shows him her working place at the radio station where she has been promoted. What puzzles the narrator is her marriage to Cornel, a man who helps around the house, a lot more than most other Romanian husbands, but who does not seem to share her passions.

Vera is a little bossy, but "charming, articulate and witty". She works in publishing and encourages Ormsby to write a book about her country. She tells him she wants to remain in Romania to make it a better place, but he later finds out from Lumi that the temptation of the Occident has been too powerful and she has accepted a job as an EU interpreter and will not come back.

\section{Middle-Aged Women}

The middle-aged women seem to be the ones that have to endure the most hardships. They no longer have the hopefulness of youth and their responsibilities have multiplied. The contrast between appearance and essence is most visible in 
their case, the most illustrative example being that of the woman he gets to sit opposite to during one of his travels by train. She has "hair frosted like a cake", "fingers dripping gold", stinks of Chanel no 5 and boasts off with her daughter's newly found wealth due to the marriage with a rich Lebanese. Yet she chews gum, which she sticks under the seat and leaves without saying goodbye.

Others, like the one who works at the cinema, enveloped in an indifference that keeps her safe, have no regard for the way they look (she wears "a faded blue cotton dress and flip-flops that have seen better beaches") or for the trouble the writer has gone through in order to get to the advertised movie they no longer want to show because they do not have enough clients. The situation changes only when the disgruntled customer threatens to write an article that would cause them bad publicity. The same indifference for the customer, the same contempt for his time is seen from the description of the meeting with a notary public who charges him 200 Euros for a free service and then she sends him to get another stamp that will be added to the other three collected from various offices around town and after having waited for hours in long ques.

The favorite past time of the women in this age group is the watching of TV and of discussing the latest TV shows, "specifically the ins-and-outs of older men who marry young girls".

There are also financially successful middle-aged ladies, like the one nicknamed Miss Lawyer who looks down her nose at the hairstylist of a posh salon. A whole chapter is dedicated to the argument of the two women regarding the refusal of the former to make an appointment before demanding a haircut. Despite being considered a brain-box, Miss Lawyer has a "long-matted pony tail that hangs from her head like oily rope on a merchant ship", wears a faded dress that "sits on her like a tent" and gives off a smell of fried onions.

Alina is the type of happily married woman who communicates with her husband not only through words, but also through looks and with whom she shares not only an intelligent child, but also a passion for mountain hiking.

Vasi's wife also loves her husband, but her love also carries maternal overtones. Her husband has returned from a mission abroad and now that he is at home, she does everything she can to make him feel loved and safe.

\section{Old Women}

Most of the women that can be included into this category have reached a certain understanding and even resignation. Life does not seem to scare them anymore and a few of these are ready to embrace on new experiences like a trip to a New York.

The old neighbors from the block participate in the meeting with the people who live in the block wearing fluffy jumpers, thick socks and flip flops and look like they want to hog all the warmth in the room. The many worries that trouble them seem to have made them forget how to smile. The difficulties of life have not managed to annul their ability to see its beauty and women like Mrs Popa, even though anxious, are friendly and like to compensate for the lack of gardens and for the desolation of the building by filling the corridors of the block with a "small jungle of thrusting vegetation".

Ormsby does not mention the age of Rodica, the wife of one of his retired friends, but we are led to understand that she is no longer young. It seems the main activities she is engaged in are watching TV while "popping sunflower seeds faster than a parrot" and muttering answers to quiz shows and cooking. The writer leaves her table "stuffed like a French goose".

Lumi's mother, a typical Romanian peasant, kisses the foreign visitor on the cheek the first time he visits them. Her skin is "smooth as marble", her eyes are clear and bright and she behaves like a child at Christmas when she gets the presents brought to her by her daughter. She is the one who seems to carry the burden of the 
household. She feeds an abandoned hungry dog, even though she scrimps on the food she gives it, and she is the one who takes care of her blind old mother. Poverty seems to plague most of the old women and Vlad's Mamaia, the widow of a war veteran, has a pension of only 25 lei after a "life spent slaving in the fields and factories". Tina is the cleaning lady who works at the author's block of flats sweeping rubbish and her possible raise of 10 lei proposed by Lumi causes a lot of stir. As the women grow old, they are at the mercy of their relatives, many of these relatives trying only to get their hands on the old ladies' meager savings. This is the case of Aneta whose apartment is eyed by her unscrupulous brother-in-law. Despite having helped a lot of people, including Lumi and her sisters, Aneta prefers to manage on her own and to organize the funeral of her husband almost single-handedly. When Lumi invites her to visit New York, she accepts ready to embark on the new adventure.

In order to make both ends meet, Maria has rented her apartment and now she can not get rid of the tenants who have not paid her rent for six months. They have also changed the locks so that she could not enter her own apartment. At the advice of the author, she sells her flat and the new owner manages to boot the tenants out. Tanti Dorina, "caught between the past and the future", with a son who never visits her, rents her house in Tusnad to hikers for 50 lei per night. She makes a lot effort in order to appear neat but the result is exaggerated: hennaed hair like candy floss, scuffed stilettos, purple polyester skirt and "purple sunglasses with a diamante motif".
She complains about being all alone, but she does not hesitate to ask 54,000 Euros for the house.

\section{Conclusion}

Mike Ormsby does not make detailed descriptions of the women he meets during his travels through Romania. He insists upon one - two defining traits or presents them engaged in a certain activity, but these elements are enough for the reader to understand the real character of the woman under scrutiny.

"Mike Ormsby's Never Mind the Balkans, Here's Romania is a valuable and noteworthy contribution to what one might call a recent trend in writing about the Romanian other as seen in the British 'mirror'. Its combination of travel impressions and journalism, shaped by means of various literary techniques, charms by its subtly humorous reflection of and on Romanianness, as discovered in Romania and abroad, in the most various circumstances, which seeks to question old clichés and stubbornly resists stereotyping" (Colipcă-Ciobanu, 2014).

The British author continues the tradition of the foreign travelers that have come to our country and that have written about the things that have impressed them as well as about the wonderful people they have met. He believes that travelling broadens the mind, but when he returns to Romania he affirms that it is good to be back home. For him Romania has become the place where he would like to establish himself and where the people have become familiar. He knows that there are less pleasant aspects about living here, but after taking all things into consideration, he reaches the conclusion that this is one of the best places in the world.

\section{REFERENCES}

Colipcă-Ciobanu, G.I. (2014). An Englishman in Romania: An Imagological Reading of Mike Ormsby's "Never Mind the Balkans, Here's Romania". Cultural Intertexts, Year 1, Vol. 1-2, available at: file:///C:/Users/mihaila.gabriela/Downloads/An Englishman in Romania An Imagological.pdf, accessed on 12 April 2021.

Ormsby, M. (2008). Never Mind the Balkans, Here's Romania. Nicoaro Books. 